\title{
ANALISYS OF RICE FARM PERFORMANCE IN JAMBI PROVINCE OF INDONESIA
}

\author{
Nainggolan Saidin*, Malik Adlaida, Napitupulu Dompak M.T. \\ Department of Agribusiness, Faculty of Agriculture, University of Jambi, Indonesia \\ *E-mail: dompakn@unja.ac.id
}

\begin{abstract}
This study was aimed to analyze the performance of wetland rice farming in Jambi Province. This study was conducted in four districts named Kerinci, Sarolangun, Bungo and East Tanjung Jabung. Data was collected by interviewing 314 rice farmers which was chosen in cluster random sampling method and analyzed both in descriptive and inferential analysis. To estimate the production and profit functions (UOP) was done by using the Cobb-Douglass function model. The results showed that: the use of production inputs was still below recommended level that made productivity low (4.36 tons /ha) compared to frontier productivity (10.3 tons / ha); the best model for estimating the production function and UOP is the Cobb-Douglass model; both simultaneous and partial analysis showed that production was significantly respond to input; never the less, all but labor inputs using are not economically efficient (VMPxi / Pxi> 1) yet. Opportunity to increase production is quite large $(37.73 \%), \mathrm{R} / \mathrm{C}$ ratio on cash cost and total costs benefited farmers and provided relatively high profitability.
\end{abstract}

\section{KEY WORDS}

Performance, production input, production, efficiency, income.

Farmer should first undertake such farm performance analysis before conducting production activities. The orientation that needs to be done by farmers is to manage production system activities. The goal of those activities is to value that these economic activities could reach an optimal input using and guaranty no waste or losses occur. This kind of necessary condition makes farmer know well the production system of his farm.

The farm performance in this study is farm production system concerning the linkage of one component (production input) with other components (output) as well as the interaction process of one another in the economic environment. More specifically, in rice farming system it includes input of production, process and output. Production input components consist of performance of land, labor, capital, management, energy, and information on input prices which play a role in performing a product. The process component in transforming production inputs into output are input control, process control itself as well as technology control as an effort to perform feedback from output to production input. This feedback effort is to maintain desired productivity is in accordance with the expectations of farmers.

Farming performance aspect has become an important discussion in farming analysis due to several reasons: (1) by having farm performance analysis a farmer or researcher know how much the contribution of each production input to output is, both simultaneously and partially, (2) both farmer or researcher know the allocation of production inputs usage in producing an optimal output, and (3) having the optimal allocation of production inputs usage, then the farmer or researcher will know the economic efficiency of input production usage, demand for input production and supply of output.

\section{METHODS OF RESEARCH}

The study was carried out in Jambi Province by taking Kerinci, Sarolangun, Bungo, and East Tanjung Jabung Districts as purposive sample areas. The four regions are the centers of rice production (rice) for the Jambi Region. The sample size is determined based on the Slovin method [1]. The sample size was 314 farmers, which is consist of 80 farmers in Kerinci Districts, 79 farmers in Sarolangun Districts, 75 farmers in Bungo Districts, and 80 
farmers in East Tanjung Jabung Districts. The samples in each region were chosen by simple random sampling method. Data was collected in survey method by using structured questionnaire. Furthermore, the data was analyzed by using the Cobb-Douglass production function model [2], profit function model (UOP) Cobb-Douglass referenced from [3]. The economic efficiency of the use of production inputs was referenced from [4] and [5], and the financial feasibility of farming was referenced from [6].

\section{RESULTS AND DISCUSSION}

Characteristics of Rice Farmers. Exposing the sampling characteristics could be expected to illustrate the social conditions and the performance of rice farmers. The characteristics of rice farmers in Jambi Province can be seen in Table 1 below.

Table 1 - Characteristics of Rice Farmers in Jambi Province in 2018

\begin{tabular}{|c|c|c|c|c|c|}
\hline \multirow{2}{*}{ No } & \multirow{2}{*}{ Characteristics } & \multicolumn{4}{|c|}{ Number of Farmer (\%) } \\
\hline & & Kerinci & Sarolangun & Bungo & East Tanjung Jabung \\
\hline \multirow[t]{6}{*}{1.} & \multicolumn{5}{|l|}{ Age (year) } \\
\hline & a. $<30$ & 4,44 & 6,66 & 10,00 & 4,35 \\
\hline & $30-<40$ & 28,89 & 33,34 & 35,00 & 26,09 \\
\hline & $40-<50$ & 44,44 & 37,78 & 30,00 & 47,83 \\
\hline & $50-<60$ & 17,78 & 15,56 & 20,00 & 17,39 \\
\hline & $\geq 60$ & 4,45 & 6,66 & 5,00 & 6,70 \\
\hline \multirow[t]{5}{*}{2.} & Farming Experience (year) & & & & \\
\hline & $<10$ & 8,89 & 6,67 & 7,50 & 13,04 \\
\hline & $10-20$ & 55,56 & 57,78 & 25,00 & 47,83 \\
\hline & $21-30$ & 22,22 & 24,44 & 37,50 & 23.91 \\
\hline & $>30$ & 13,33 & 11,11 & 30,00 & 15,22 \\
\hline \multirow[t]{5}{*}{3.} & \multicolumn{5}{|l|}{ Education (level) } \\
\hline & Elementary School & 17,78 & 24,44 & 30,00 & 32,61 \\
\hline & Junior High School & 55,56 & 48,90 & 45,00 & 43,48 \\
\hline & Senior High School & 22,22 & 22,22 & 22,50 & 19,56 \\
\hline & Graduate (University) & 4,44 & 2,50 & 2,50 & 4,35 \\
\hline \multirow[t]{3}{*}{4.} & House Hold Member (person) & 35,56 & 22,22 & 20,00 & 39,13 \\
\hline & $2-3$ & 44,44 & 44,44 & 52,50 & 45,65 \\
\hline & $\begin{array}{l}4-5 \\
>5\end{array}$ & 20,00 & 33,34 & 27,50 & 15,22 \\
\hline
\end{tabular}

Data presented above shows that most farmer in Jambi Province are in productive age, with formal education levels mostly are at the primary school level. All Farmers have experience in farming rice fields over eight years. The average number of dependents of farmer families is $4-5$ persons with the average age is below 20 years so the dependency ratio is a little bit high.

Description of Rice Farming Technology Application. In general, research showed that most $(85,03 \%)$ of rice farmers perform the concept of Integrated Crop Management (ICM) system in running their farm while the rest has not found doing the same system yet. The main reason of farmer to carry out the ICM system is to increase crop productivity sustainability. The research also showed that one of the ICM components carried out by farmer in Jambi Province is the use of recommended superior rice varieties. It was found that 92,04\% rice farmer in Jambi Province use recommended superior rice varieties in 2018. Nevertheless, it was also found that almost a half $(47,40 \%)$ of those farmer does not use certified and high-vigor seeds and as many as $12,11 \%$ of farmer does not pay attention to seed quality. The use of seeds ranges from 8 to $21 \mathrm{~kg} / \mathrm{ha}$, and seedling age is 18 to 25 days. Soil processing is carried out by double hijacking; inundated periods range from 15 to 21 days with a ratio of mud and water 1:1. Number of seeds is 2 to 3 seeds per planting hole with hole spacing is $15 \times 15 \mathrm{~cm}$, most adopted planting style was the new jajar legowo style which is based on the planting pair rows spacing. There are two types of recommended jajar legowo style in Jambi Province i.e.: 2:1:3 and 1:4:1 planting system. The fertilization dosage and applying periods are not as recommended yet. Nitrogen dose was in average $150 \mathrm{~kg} / \mathrm{ha}$ 
with two application periods. $\mathrm{P}$ and $\mathrm{K}$ fertilizer was applied at the age of 7-10 days after planting with a dose of $100 \mathrm{~kg} \mathrm{ha}^{-1}$ in form of TSP and $100 \mathrm{~kg} \mathrm{ha}^{-1}$ in form of KCl. Irrigating paddy fields was as recommended with a height of $2-3 \mathrm{~cm}$ and carried out interrupted in dry conditions and irrigated again. Rice fields are dried in 10 days before harvest. Farmers conduct pest control in an integrated manner, especially in fighting rats and snails. Weed control is carried out by more perfect soil management, regulating water in paddy fields and using herbicides. Harvest is done by using a serrated crescent tool, harvesting machine and threshing and the grain is stored in water content of less than $14 \%$ and less for food and $13 \%$ for seeds. Planting indexes are 100 and 200, means one and two times planting season in one year. Cultivated wetland rice fields in Jambi Province ranges from rainfed, simple irrigation and technical irrigated rice fields. Distribution of wetland rice farming in Jambi Province is presented in Table 2.

Table 2 - Classification of Smallholder Rice Farming in Jambi Province, 2018

\begin{tabular}{|c|c|c|c|c|c|}
\hline \multirow{2}{*}{ No } & \multirow{2}{*}{ Description } & \multicolumn{4}{|c|}{ Number of Farmer [\%] } \\
\hline & & Kerinci & Sarolangun & Bungo & East Tanjung Jabung \\
\hline \multirow[t]{4}{*}{1.} & Rice farm area (ha) & & & & \\
\hline & $\leq 1.0$ & 68,89 & 48,89 & 45,56 & 10,86 \\
\hline & $1.01-\leq 2.0$ & 22,22 & 35,56 & 35,00 & 43,49 \\
\hline & $2.0>$ & 8,89 & 15,55 & 20,00 & 45,65 \\
\hline \multirow[t]{3}{*}{2.} & Planting Style & & & & \\
\hline & a. Jajar legowo & 20,00 & 57,33 & 45,56 & 73,75 \\
\hline & Other style & 80,00 & 42,67 & 54,44 & 26,25 \\
\hline \multirow[t]{3}{*}{3.} & Seed used & & & & \\
\hline & a. As recommended & 11,11 & 4,44 & 5,00 & 4,35 \\
\hline & Other varieties & 88,99 & 95,56 & 95,00 & 95,65 \\
\hline \multirow[t]{3}{*}{4.} & $\mathrm{~N}$ fertilizer dosage & & & & \\
\hline & a. As recommended & 4,44 & 2,22 & 2,50 & 0,00 \\
\hline & b. Other dosage & 95,56 & 97,78 & 97,50 & 100,00 \\
\hline \multirow[t]{3}{*}{5.} & $\mathrm{P}$ fertilizer dosage & & & & \\
\hline & a. As recommended & 6,67 & 2,22 & 2,50 & 0,00 \\
\hline & Other dosage & 93,33 & 97,78 & 97,50 & 100,00 \\
\hline \multirow[t]{3}{*}{6.} & $\mathrm{~N}$ fertilizer dosage & & & 1 & \\
\hline & a. As recommended & 4,44 & 2,22 & 2,50 & 2,17 \\
\hline & Other dosage & 95,56 & 97,78 & 97,50 & 97,83 \\
\hline \multirow[t]{4}{*}{7.} & Harvesting methods & & & & \\
\hline & Manual & 33,33 & 57,78 & 67,50 & 60,87 \\
\hline & Mechanic & 44,45 & 20,00 & 12,50 & 10,87 \\
\hline & Other & 22,22 & 22,22 & 20,00 & 28,26 \\
\hline \multirow[t]{2}{*}{8.} & Cropping Pattern & & & & \\
\hline & Rice - secondary- rice & 55,55 & 17,78 & 45,00 & 10,87 \\
\hline
\end{tabular}

Statistical data shows that these four districts is the center of rice production in Jambi Province. Government should have focused its policy on altering rice farm production in these four districts. However most of the time various government efforts go unproductive. It can be seen in Table 2 that most of rice farmers in Kerinci, Sarolangun and Bungo Districts own less than 1,01 ha of wet land. That relatively small farm area makes them unpowerful in accumulating capital to make their farm sustain and adopt new technology introduced. Most small farmer in Kerinci and Bungo for instance fail to adopt new planting style "jajar legowo" that has been well proven successful in lifting rice productivity in some other area $[7,8]$.

Rice farmer's failure in adopting new technology was also shown by low quality input application. There was very view farmer in Jambi Province who used recommended seed and fertilizer in their rice farm production process. These unexpected production behaviour of course make them ail to produce more rice and collect more income from their rice farm. As it could be seen in Table 2 above there were at most 11,11\% of rice farmer in Kerinci District has adopted new rice seed variety as recommended and no more than $5 \%$ who doing the same thing in the rest districts. The same phenomena also shown in using high technology input fertilizer that no more than $6,67 \%$ of them apply enough fertilizer as recommended. 
Working Capital Structure. Data showed that the amount of working capital needed by farmers is between Rp. 5.16 - 6.38 million per hectare per season. The capital is needed to finance rice farming starting from land preparation until harvesting. Most of the fund comes from farmer household capital as well as loans from Gapoktan and the owner of Rice Milling Unit (RMU). The details of the working capital structure of wetland rice in Jambi Province are presented in Table 3.

Table 3 - Working Capital Structure of Paddy Rice Farming in Jambi Province, 2018

\begin{tabular}{llllll}
\hline Capital Structure & \multicolumn{5}{c}{ District } \\
\cline { 2 - 6 } (Rp. 000/Ha) & Kerinci & Sarolangun & Bungo & Tanjabtim & Average \\
\hline Farmer Household & $3.655,56$ & $2.915,60$ & $2.833,99$ & $2.785,50$ & $3.047,66$ \\
Gapoktan (Farmer Group) & $1.875,00$ & $1.685,75$ & $1.529,21$ & $1.725,65$ & $1.703,90$ \\
Trader or RMU Owner & 850,00 & 800,00 & 875,00 & 650,00 & 793,75 \\
Working Capital Needed & $6.380,56$ & $5.401,35$ & $5.238,20$ & $5.161,15$ & $5.545,32$ \\
\hline
\end{tabular}

Data presented on Table 3 shows that working capital of lowland rice farming is still dominated by own capital. This is based on the idea that the family of farmers is generally relatively able to meet the working capital needs of their farming by reducing the use of inputs. Government programmed through such as Upsus Program on working capital is still relatively small. This is supported by data obtained in the study that additional capital from the Upsus Program received by farmers ranged from $\mathrm{Rp} 1.25-2.5$ million. The amount of Upsus Program funds is only sufficient about $18-38 \%$ of the real working capital needed by farmers. The availability of farmers' capital for the next planting season is strongly influenced by the sale of crops.

Inputs Use. Production inputs have not been optimal causing productivity of paddy farming has not optimal yet. This also could illustrate the performance of farmers in managerial skills that is still quite low. Un-optimal use of inputs on the other hand is reflecting that the opportunity to increase productivity is also quite large because the gap between the actual level of productivity and the maximum level of productivity that can be achieved with the best practiced system is also quite large. Comparison of input and output use among farmer groups can be seen in Table 4 .

Table 4 - Average Land Area, Results, and Use of Input of Rice Paddy Farming in Jambi Province, 2018

\begin{tabular}{|c|c|c|c|c|c|c|c|}
\hline \multirow{2}{*}{ No } & \multirow{2}{*}{\multicolumn{2}{|c|}{ Description }} & \multicolumn{4}{|l|}{ District } & \multirow{2}{*}{ Average } \\
\hline & & & Kerinci & Sarolangun & Bungo & East Tanjung Jabung & \\
\hline \multirow[t]{3}{*}{1} & \multicolumn{7}{|c|}{ Production } \\
\hline & \multicolumn{2}{|c|}{ Rice field area $(\mathrm{Ha})$} & 0,28 & 0,76 & 0,85 & 1,35 & 0,81 \\
\hline & \multicolumn{2}{|c|}{ Production $(000 \mathrm{~kg} / \mathrm{ha})$} & 5,75 & 4,45 & 4,37 & 2,86 & 4,36 \\
\hline \multirow[t]{11}{*}{2} & \multicolumn{7}{|c|}{ Input } \\
\hline & 1) & Seed (kg/ha) & 20,50 & 25,50 & 28,60 & 30,50 & 26,27 \\
\hline & 2) & Fertilizer (kg/ha) & & & & & \\
\hline & a. & $\mathrm{N}$ & 108,00 & 85,00 & 65,00 & 35,00 & 73,25 \\
\hline & b. & $P$ & 55,00 & 40,00 & 35,00 & 20,00 & 37,50 \\
\hline & c. & K & 42,00 & 25,00 & 25,00 & 18,00 & 27,50 \\
\hline & d. & Organic & 1200,00 & 800,00 & 700,00 & 500,00 & 800,00 \\
\hline & 3) & Insecticide & 2500,00 & 1500,00 & 600,00 & 500,00 & 1275,00 \\
\hline & 4) & Labor & 85,00 & 78,50 & 70,50 & 62,50 & 74,12 \\
\hline & a. & Hired & 20,00 & 30,00 & 50,50 & 50,50 & 37,75 \\
\hline & b. & Household & 70,00 & 63,50 & 35,00 & 27,00 & 48,87 \\
\hline
\end{tabular}

Data analysis showed that some variables such as land area, production, fertilizer $(\mathrm{N}$, and $\mathrm{K}$ ) used, and total hired labor were significantly different between the four districts, while the use of seeds, fertilizer-P, and household labor were not significantly different each other. One interesting thing could be mention here is that even though the rice field area in Kerinci District is significantly smaller than the other districts rice field, an average rice farmer in this district could produce significantly higher rice per hectare. This is perhaps because of higher fertilizer input used in this area. It could be seen that all type of fertilizer, N, P, K and organic 
used by rice farmer in Kerinci District is significantly higher than their colleague in Soralangun, Bungo and East Tanjung Jabung Districts.

Cost and Revenue. All business includes rice farmer expect maximum income generated from their business. The final results expected by farmers from each process of their farming production are maximum profit. The income of wetland rice farming in this study was obtained from total revenue (TR) minus total costs (TC) of rice farming production.

Table 5 - Average Revenue, Cost and Income of Paddy Rice Farmers in Jambi Province in 2018

\begin{tabular}{llllll}
\hline \multirow{2}{*}{ Description } & \multicolumn{3}{c}{ District } & \multirow{2}{*}{ Average } \\
\cline { 2 - 5 } Revenue (Rp. 000/Ha) & Kerinci & Sarolangun & Bungo & East Tanjung Jabung & $11.368,71$ \\
Cost (Rp. 000/Ha) & $14.595,60$ & $12.722,40$ & $9.900,14$ & $8.256,70$ & \\
A. Cash Cost & & & & 123,39 \\
1. Seed & 128,65 & 124,59 & 121,97 & 118,35 & 1171,13 \\
2. Fertilizer & 1309,52 & 1286,00 & 1248,25 & 840,80 & 111,73 \\
$\quad$ a. N & 145,75 & 101,69 & 104,24 & 95,25 & 79,58 \\
$\quad$ b. SP 36 & 95,43 & 93,81 & 53,61 & 75,47 & 812,50 \\
$\quad$ C. KCL & 900,00 & 900,00 & 900,00 & 550,00 & 167,32 \\
$\quad$ d. Organic & 168,34 & 190,50 & 190,40 & 120,07 & $1.622,70$ \\
3. Insecticide & $1.850,80$ & $1.789,26$ & $1.300,24$ & $1.550,50$ & $1.164,68$ \\
4. Hired Labor & $2.574,09$ & $2.447,93$ & $1.898,82$ & $2.084,65$ & $4.081,90$ \\
$\quad$ Total Cash Cost & $5.863,06$ & $5.647,78$ & $4.569,28$ & $4.594,30$ & $1.635,77$ \\
B. Non- Cash Cost & & & & & 650,00 \\
1. Household labor & $1.956,70$ & $1.455,20$ & $1.256,00$ & $1.875,20$ & $2.285,77$ \\
2. Rent for Land & 850,00 & 500,00 & 500,00 & 750,00 & $6.367,67$ \\
$\quad$ Total Non-Cash Cost & $2.806,70$ & $1.955,20$ & $1.756,00$ & $2.625,20$ & $7.286,81$ \\
C. Total Cost & $8.669,76$ & $7.602,98$ & $6.325,28$ & $7.219,50$ & $5.001,04$ \\
D. Revenue on Cash Cost & $8.732,54$ & $7.074,62$ & $5.330,86$ & $3.662,40$ & 2,79 \\
E Revenue on Total Cost & $5.925,84$ & $5.119,42$ & $3.574,86$ & $1.037,20$ & 1,79 \\
R/C ratio on Cash Cost & 2,49 & 2,25 & 2,17 & 1,80 & 1,14 \\
R/C ratio on Total Cost & 1,68 & 1,67 & 1,57 & 1,67 & \\
\hline
\end{tabular}

Table 5 shows that the amount of cash costs paid by farmers is relatively different among the four group of farmers based on region in Jambi Province. Rice farmer in East Tanjung Jabung paid the least cash cost ( $R p$ 8.256,70 thousand) while their colleagues in Kerinci District paid the highest cash cost (Rp 14.595,60 thousand). The average revenue made by rice farmer in Jambi Province was Rp 11.368,71 thousand.

Somehow different with the revenue schedule, average farmer in Kerinci District paid the highest total cost (Rp 8.669,76 thousand) among the four groups of farmers, while the lowest cost was paid by farmer in Bungo District. The different in cost paid was mainly due to the different in insecticide and labor input used. As it can be seen in Table 5 above an average rice farmer in Kerinci District paid Rp 1850,80 thousand per hectare for insecticide while the rest farmer pays lower particularly rice farmer in Bungo District. An average farmer in Kerinci also paid labor wage higher (Rp 2574,09 thousand) than the other farmers at other districts. It could be seen that the highest expenditure was for paid labor costs, Rp. 1,164,68 thousand per ha or $28.53 \%$ of the total cash cost or $18.29 \%$ of the total cost. Cash paid for seeds, N, SP36, $\mathrm{KCl}$, organic fertilizers and chemical insecticides are relatively small.

Like it can be seen in cash cost paid, non-cash cost of Kerinci rice farmer was higher than other regions rice farmers in Jambi Province. More intensive household labor use in Kerinci rice farm as well as higher rent land value made the total cost become higher than the other farmers. As it can be seen in Table 5 above, an average total cost of rice farm in Kerinci District was Rp 8.669,76 thousand per hectare per season is higher than the average total cost of rice farm (Rp 8.669.760) per hectare per season in Jambi Province. The RC farmer ratios over the total cost was $1,79>1$, this means that economically rice farming is still feasible in Jambi Province. Every Rp 10 rice farm cost could provide revenue as much as Rp. 17,9 or generated net income as much as Rp. 7,9 . If labor costs in the family and land rent are not calculated as costs, the average cash income per hectare of the farmer is relatively greater. The $\mathrm{RC}$ ratio of cash costs is 2,79 , which means that each cash 
expenditure is Rp. 10, it can provide revenue of Rp. 27,9 or provide net income as much as Rp. 17,9. This shows that family labor has job opportunities that can provide a good source of income for farmers by farming in the fields.

Production Functions. Estimating the production function is aimed to discuss the influence of inputs used on output, or more specific, it is aimed to know how the responds of production to the use of production inputs. By using response analysis, it can be known; (1) which input influences output from the least to the most (2) which combination of inputs most influences the output, (3) the use of optimum input to produce the highest output. In this study, estimation of the production function that is expected to be accordance with the nature of rice farming is the Cobb-Douglas, Transcendental and Inversion log functions. The results of statistical analysis are presented in Table 6.

Table 6 - Results of estimation of Rice Paddy Farm Production Function in Jambi Province, 2018

\begin{tabular}{|c|c|c|c|c|c|c|c|}
\hline \multirow{3}{*}{ No } & \multirow{3}{*}{ Variable } & \multicolumn{6}{|c|}{ Production Function } \\
\hline & & \multicolumn{2}{|c|}{ Cobb Douglass } & \multicolumn{2}{|c|}{ Transcendental } & \multicolumn{2}{|c|}{ Invers log-log } \\
\hline & & Koef & Sig & Koef & Sig & Koef & Sig \\
\hline 1 & Land $\left(\mathrm{X}_{1}\right)$ & 0,6872 & 0,0000 & 0,4356 & 0,0000 & 0,5631 & 0,0000 \\
\hline 2 & Seed $\left(X_{2}\right)$ & 0,0983 & 0,0347 & $-0,3451$ & 0,0000 & 0,0352 & 0,0721 \\
\hline 3 & $\mathrm{~N}$-fertilizer $\left(\mathrm{X}_{3}\right)$ & 0,8354 & 0,0000 & 0,2435 & 0,0000 & 0,0087 & 01348 \\
\hline 4 & $\mathrm{SP}_{36}$-fertilizer $\left(\mathrm{X}_{4}\right)$ & 0,1875 & 0,0253 & 0,0041 & 0,0935 & 0,0062 & 0,1456 \\
\hline 5 & KCL-fertilizer $\left(X_{5}\right)$ & 0,0656 & 0,0376 & 0,0135 & 0,0843 & $-0,0578$ & 0,0582 \\
\hline 6 & Organic-fertilizer $\left(\mathrm{X}_{6}\right)$ & 0,0837 & 0,0342 & 0,0072 & 0,1067 & 0,0076 & 0,0856 \\
\hline 7 & Insecticide $\left(\mathrm{X}_{7}\right)$ & 0,0821 & 0,0367 & 0,0768 & 0,0634 & 0,0245 & 0,0733 \\
\hline 8 & Labor $\left(\mathrm{X}_{8}\right)$ & 0,1154 & 0,0352 & 0,3125 & 0,0341 & $-0,1257$ & 0,0425 \\
\hline 9 & Constants & 2,1157 & 0,0000 & 1,2116 & 0,0000 & 1,5562 & 0,0000 \\
\hline 10 & Adj. $R^{2}$ & 0,7872 & & 0,7345 & & 0,7056 & \\
\hline
\end{tabular}

It can be seen at Table 6 that the estimated parameters that produce a high degree of precision are Cobb-Douglass production function models with Adjusted $R^{2}=0.7872$, while the other models, Transcendental (0.7345) and Inversion log-log (0.7056) come lower. Also, it can be seen that the Cobb-Douglass production function models shows that all variables are significantly $(\alpha<0,05)$ influence the level of rice production in Jambi Province. Never the less, all three types of production functions show that the land area variable includes as a determinant in production function as it is significantly different from zero at the level of $99 \%$. The Value of Adjusted $\mathrm{R}^{2}=0.7872$ means that $78.72 \%$ of variation in rice production can be explained by variables input use. All variable factors have a parameter with a positive sign and are real at the level of $95 \%$. This means that any increase in the use of production inputs will increase farm production. The land area and $\mathrm{N}$ fertilizer have the greatest influence on production among the production inputs used. The 10\% increase in land area; seeds; N, SP36, $\mathrm{KCl}$, and Organic fertilizer; chemical insecticides and labor will increase production by $6.872 \%, 0.983 \%, 8.354 \%, 1.875 \%, 0.656 \%, 0.837 \%, 0.821 \%$ and $1,154 \%$. The accumulation of all parameter values from variable factors as the size of return to scale as it is presented at Table 6 is obtained $\Sigma$ bi $=2.1552>1$ (one). This means that rice farming in this area is experiencing increasing returns to scale. The used of input variables all together are still in phase two that means not efficient yet.

Input Used Efficiency. Efficiency of farming management is related to farmer managerial abilities. The use of inputs is said to be efficient if the use of fewer inputs can produce more production. Such a situation will occur if the farmer is able to make an attempt at a marginal product value (MPV) for an input equal to the input price $\left(P x_{i}\right)$ or $\left(M P V x_{i}=P x_{i}\right)$, or allocative efficiency. The allocative efficiency of lowland rice farming in Jambi Province can be seen in Table 7 below. Data shows that all variables included in the model except Labor $\left(X_{8}\right)$ are not efficient which can be seen from value IE $=M P V x / P x>1$. This means that land use, seeds, N, SP $36, \mathrm{KCl}$, organic fertilizers, chemical insecticides need to be added but labor use need to be reduced. To achieve efficiency, the input of $X_{1-7}$ needs to be added, because the production area is in the area of Increasing return to scale. This means that farmers still have a great opportunity to obtain a number of productions which is quite profitable if a number of production inputs are added. 
Table 7 - Results of Analysis of Allocative Efficiency of Paddy Rice Farming in Jambi Province in 2018

\begin{tabular}{lllllllll}
\hline Variable & bi & $y i / x i$ & $\mathrm{MPx}_{i}$ & $\mathrm{Py}$ & $\mathrm{MPVx}_{\mathrm{i}}$ & $\mathrm{Px}_{\mathrm{i}}$ & $\mathrm{IE}$ & Need \\
\hline Land $\left(\mathrm{X}_{1}\right)$ & 0,6872 & 4355 & $2.992,75$ & 4.500 & 13.467 .402 & 2.500 .000 & 5,386 & more \\
Seed $\left(\mathrm{X}_{2}\right)$ & 0,0983 & 59,45 & 5,84 & 4.500 & $26.297,70$ & 10.000 & 2,629 & more \\
N-fertilizer $\left(\mathrm{X}_{3}\right)$ & 0,8354 & 165,74 & 138,45 & 4.500 & $62.3066,38$ & 2.300 & 270,89 & more \\
SP & 0,1875 & 116,13 & 21,77 & 4.500 & $97.984,68$ & 2.350 & 41,69 & more \\
KCL-fertilizer $\left(\mathrm{X}_{4}\right)$ & 0,0656 & 158,36 & 10,388 & 4.500 & $46.747,87$ & 2.300 & 20,325 & more \\
Organic-fertilizer $\left(\mathrm{X}_{5}\right)$ & 0,0837 & 5,12 & 0,428 & 4.500 & $1.928,45$ & 1.800 & 1,071 & more \\
Insecticide $\left(\mathrm{X}_{7}\right)$ & 0,0821 & 2,17 & 0,178 & 4.500 & 801706 & 2.500 & 1,603 & more \\
Labor $\left(\mathrm{X}_{8}\right)$ & 0,1154 & 58,77 & 6,78 & 4.500 & 30519,3 & 75.000 & 0,407 & less \\
\hline
\end{tabular}

Factors Affecting the Benefits of Rice Farming. A difficulty in achieving maximum profit by most of rice farming can be caused by: (1) lack of understanding about the principle of input output relations that caused actual production to be low, (2) failure in handling farm high risk, (3) uncertainty about future prices, and (4) limitations in providing fertilizer due to limited capital and low skills. Factors of inputs prices and farm output most of the time affects the size of farmers' profits. The results of estimating the profit function of the Output Price Unit (UOP) can be seen in Table 8.

Table 8 - Results of Regression Analysis of Factors Affecting the Benefits of Rice Farming, 2018

\begin{tabular}{lll}
\hline Variable & Coefficient of Regress & Sig. \\
\hline Land rent & 0,5456 & 0,0022 \\
Seed price & $-0,2752$ & 0,0256 \\
Price of N-Fertilizer & 0,8556 & 0,0001 \\
Price of SP 36- Fertilizer & 0,3562 & 0,0164 \\
Labor wage & $-2,5778$ & 0,0000 \\
Price of KCl- Fertilizer & $-3,8645$ & 0,0000 \\
Price of Organic Fertilizer & $-0,6742$ & 0,0018 \\
Insecticide Price & 1,6772 & 0,0000 \\
Dummy Variable March Planting Period & 27,4563 & 0,0000 \\
Dummy Variable July Planting Period & $-25,4113$ & 0,0000 \\
Dummy Variable November Planting Period & $-14,5621$ & 0,0000 \\
Intercept & 0,6135 & 0,0000 \\
\hline Adj. R & 0,8240 & 0,0000 \\
F Value & 36.422 & \\
\hline
\end{tabular}

Table 8 shows that $F$ statistic was 36,422 with Probability of $F$ statistic equal to 0,0000 . This means that the profit function estimation model can clearly explain the effect of production inputs on profits. Adj. $R^{2}$ value is 0,8240 , meaning that $82,40 \%$ of the variation in the amount of profit can be explained simultaneously by the production inputs included in the model. The amount of interception $\left(b_{0}\right)$ was 0,622 , this value indicates the amount of technical efficiency and is in the category of quite low because ET $=0,62<0,7$. Not all coefficients of the variable are negative and the fixed variable is positive. Negative magnitude is an indication of the existence of a negative relationship between the price of input and the demand for input. That is, the higher the price of the input the less input is used and ultimately reduces the amount of profit received. Conversely for fixed variables (land area) is positive, which means that the land area has a positive relationship with profit. The price of seed, labor, and $\mathrm{KCl}$ fertilizer variables has a negative relationship with profits because the demand for these inputs decreases. The price of N, SP36, organic fertilizer and chemical insecticides input has a positive relationship. This means that even though the input price rises, the demand for inputs also increases and will be followed by an increase in the amount of profits that farmers will receive. The conditions in the dummy show positive numbers in the March planting season, and negatives in the July planting season and the November planting season, this indicates that farmers will be benefited relatively more in the March planting season compared to the amount of profits in other planting seasons, July and November. 


\section{CONCLUSION AND POLICY IMPLICATIONS}

The results showed that the use of production inputs was all below the number of recommendations and productivity $(4,36$ tons / ha) classified as low far below the frontier productivity (10,3 tons / ha). The simultaneous and partial response to production is influenced by actual production inputs. Technical efficiency is low $(E T=0,6227<0,7)$ and all uses of production inputs are not economically efficient (MPV $\left.x_{i} / P x_{i}>1\right)$ and need to be added except for labor. Opportunities to increase production are quite large $(37,73 \%), \mathrm{RC}$ ratio of cash costs and total costs benefit farmers and provide relatively high profitability.

In order to increase technical efficiency, the government needs to expand and improve irrigation networks and help farmers some working capital by conducting guidance and supervision of the aid channeled so that the assistance is appropriate to finance the procurement of production facilities. Local governments need to empower farmer groups in providing collective input and marketing of products through a partnership network. Therefore, farmers are expected to be able to improve technical efficiency, allocative and more profitable economic efficiency.

\section{REFERENCES}

1. Sugyiono, 2008. Metode Penelitian Kuantitatif and Kualitatif. Penerbit Alpabeta, Bandung.

2. Soekartawi, 2008. Teori Ekonomi Produksi dengan Pokok Bahasan Analisis Fungsi Cobb-Douglass. Raja Grafindo Persada, Jakarta.

3. Tasman, Aulia, 2008. Ekonomi Produksi (Analisis Efisiensi and Produktifitas) Chandra Pratama, Jakarta.

4. Masyhuri, 2007. Ekonomi Mikro.Penerbit UIN Malang Press, Malang.

5. Laila Husin and Litianthi, 2008. Ekonomi Produksi Pertanian (Analisis Secara Teoritis and Kuantitatif). Fakultas Pertanian UNSRI, Palembang.

6. Suratiyah, Ken, 2014. IImu Usahatani. Penerbit Swadaya, Jakarta.

7. Ikhwani, Gagad Restu Pratiwi, Eman Paturrohman and A.K. Makarim. 2013. Peningkatan Produktivitas Padi Melalui Penerapan Jarak Tanam Jajar Legowo (Increasing Rice Productivity through the Adoption of Pair Rows Spacing).

8. Kiki Kusyaeri Hamdani and Sri Murtiani. 2014. Application of Jajar Legowo Planting System to Increase Paddy Yield. Balai Pengkajian Teknologi Pertanian (BPTP) Jawa Barat. 